\title{
Efektivitas Pembelajaran Daring Peserta Didik (Suatu Penelitian Pada Mata Pelajaran Biologi SMA Terpadu Wira Bhakti Gorontalo)
}

\author{
Lilan Dama ${ }^{1}$, Ilyas H. Husain ${ }^{2}$, Nurelviana ${ }^{3}$ \\ Jurusan Biologi Universitas Negeri Gorontalo \\ Ilyashusain@ung.ac.id
}

\begin{abstract}
Abstrak: Penelitian ini bertujuan untuk mengetahui efektifitas penerapan pembelajaran daring pada mata pelajaran biologi melalui pengaturan belajar inkuiri terbimbing (guided inquiry) Penelitian ini melibatkan peserta didik kelas X IPA SMA Terpadu Wira Bhakti Gorontalo yang berjumlah 30 orang peserta didik. Jenis penelitian ini merupakan penelitian deskriptif kualitatif. Adapun teknik pengumpulan data yang digunakan pada penelitian ini melaui wawancara dan penyebaran angket/kuesioner pre-test \& post-test. Selanjutnya data yang telah diperoleh dianalisis keteracapaian hasil belajar peseserta didik secara umum dapat digambarkan dengan deskripsi terhadap nilai rata-rata hasil belajar peserta didik di dalam kelas selanjutnya data nilai tes hasil belajar dianalisis dengan rumus presentasi ketuntasan belajar individu. Hasil penelitian ini menunjukkan bahwa jika dilihat dari hasil belajar nilai rata-rata mata pelajaran biologi siswa kelas X IPA pada pembelajaran daring semester genap 2019/2020 diperoleh nilai memenuhu nilai ketuntasan Minimal (KKM) untuk mata pelajaran biologi sebesar 70. Berdasarkan hasil penelitian diatas maka dapat dikatakan bahwa jika dilihat perolehan nilai rata-rata hasil belajar siswa pada semester genap maka pembelajaran daring dapat dikatakan telah efektif. Namun jika dilihat dari berbagai masalah yang dihadapi maka dapat dikatakan bahwa pembelajaran daring tersebut masih kurang efektif dan masih harus terus ditingkatkan dan diperhatikan lagi baik itu dari guru maupun dari siswa.
\end{abstract}

Kata Kunci: Pembelajaran Daring; Efektifitas pembelajaran; Wira Bhakti Gorontalo

\begin{abstract}
This study aims to determine the effectiveness of the application of online learning in biology subjects through guided inquiry learning arrangements (guided inquiry). This study involved 30 students of class X IPA SMA Terpadu Wira Bhakti Gorontalo. This type of research is qualitative descriptive research. The data collection techniques used in this study were through interviews and the distribution of pre-test \& post-test questionnaires/questionnaires. Furthermore, the data that has been obtained is analyzed the achievement of student learning outcomes, in general, can be described by a description of the average value of student learning outcomes in the class then the data on the test scores of learning outcomes is analyzed by the presentation formula of individual learning completeness. The results of this study indicate that when viewed from the study results the average value of biology subjects for class $X$ science students in online learning even semester 2019/2020 obtained a score that meets the Minimum Completeness Score (KKM) for biology subjects is 70 . Based on the results of the research above, it can be said that if it is seen that the average value of student learning outcomes in even semesters, online learning can be said to have been effective. However, when viewed from the various problems faced, it can be said that online learning is still less effective and still needs to be improved and paid attention to both from teachers and students.
\end{abstract}

Keywords: Online Learning; Effectiveness of learning; Wira Bhakti Gorontalo 


\section{Pendahuluan}

Teknologi informasi dan komunikasi di era industri 4.0 telah mengalami perkembangan yang sangat pesat dan memiliki pengaruh yang sangat besar terhadap proses pembelajaran dan pengajaran. Para pengajar harus dapat memanfaatkan kemudahankemudahan dalam mengakses teknologi agar dapat meningkatkan kualitas pendidikan terutama di Indonesia. Perkembangan teknologi dapat memberikan perubahan-perubahan terhadap proses pelaksanaan pembelajaran (Khusniyah \& Hakim, 2019). Perkembangan teknologi informasi juga telah mendorong munculnya berbagai inovasi dalam model pembelajaran di bidang pendidikan. Model pembelajaran berbasis teknologi muncul karena terdapat kendala pada metode pembelajaran tradisional khususnya untuk saat ini di tengah pandemi COVID-19 yang dapat mengancam keselamatan sehingga peserta didik tidak dapat bertatap muka atau terlibat aktif dalam proses pembelajaran (teacher-directed learning) (Wicaksana dkk, 2020).

Salah satu bentuk pembelajaran alternatif yang dapat dilaksasnakan selama masa darurat Covid-19 adalah pembelajaran secara online. Menurut Moore, Dickson-Deane, \& Galyen (2011) dalam Firman (2020) Pembelajaran online merupakan pembelajaran yang menggunakan jaringan internet dengan aksesibilitas, konektivitas, fleksibilitas, dan kemampuan untuk memunculkan berbagai jenis interaksi pembelajaran. Penelitian yang dikakukan oleh Zhang et al., (2004) menunjukkan bahwa penggunaan internet dan teknologi multimedia mampu merombak cara penyampaian pengetahuan dan dapat menjadi alternatif pembelajaran yang dilaksanakan dalam kelas tradisional. Pembelajaran online pada pelaksanaannya membutuhkan dukungan perangkat-perangkat mobile seperti telepon pintar, tablet dan laptop yang dapat digunakan untuk mengakses informasi dimana saja dan kapan saja (Gikas \& Grant, 2013). Berbagai media juga dapat digunakan untuk mendukung pelaksanaan pembelajaran secara online. Misalnya kelas-kelas virtual menggunakan layanan Google Classroom, Edmodo, dan Schoology (Enriquez, 2014; Sicat, 2015; Iftakhar, 2016), dan applikasi pesan instan seperti WhatsApp (So, 2016). Pembelajaran secara online bahkan dapat dilakukan melalui media social seperti Facebook dan Instagram (Kumar \& Nanda, 2018).

Pembelajaran biologi di tengah pandemi Covid-19 dengan protokol physical distancing yang diberlakukan pemerintah, ruang gerak pembelajarannya terhadap peserta didik terbatas lantaran physical distancing juga diberlakukan dalam lembaga pendidikan. Interaksi antara pendidik dan siswa pada proses pembelajaran tidak dapat diperoleh pada kondisi saat ini. Namun begitu, muncul keraguan mengenai efektifitas pembelajaran berbasis daring dalam proses pembelajaran. Kondisi demikian jelas mempengaruhi efektivitas pembelajaran biologi. Pada mulanya, pembelajaran biologi dapat berjalan dengan baik tanpa adanya pembatasan jarak, kini terganggu akibat adanya pandemi Covid19 yang mengalihkan pembelajaran berbasis daring sehingga peserta didik tidak dapat leluasa melakukan pembelajaran doing the real thing yang memberikan banyak pengalaman. Berdasarkan kondisi tersebut, tulisan ini mengambil posisi sebagai bagian yang berpandangan bahwa peserta didik adalah objek pembelajaran yang paling konkret pada mata pelajaran biologi.

Berdasarkan hal diatas maka peneliti merasa perlu untuk mengkaji dengan melibatkan guru mata pelajaran dan peserta didik kelas X IPA yang ada di SMA Terpadu Wira Bhakti Gorontalo bahwa proses pembelajaran daring masih kurang efektif khususnya pada materi Ruang Lingkup Biologi karena pengaplikasian pembelajaran daring yang mereka peroleh hanya berpusat pada pemberian tugas, rasio pemberian materi sangatlah kecil, akses bertanya juga tidak seluas pada saat pembelajaran tatap muka baik bertanya pada guru maupun pada teman. 


\section{Metode Penelitian}

Jenis penelitian ini merupakan penelitian kualitatif. Metode yang digunakan dalam penelitian ini adalah deskriptif. Menurut Sutopo (2006) penelitian kualitatif yaitu penelitian yang mengarah pada pendeskripsian secara rinci dan mendalam baik kondisi maupun proses, dan juga hubungan atau saling keterkaitannya mengenai hal-hal pokok yang ditemukan pada sasaran penelitian. Tujuan digunakkan metode deskriptif ini adalah untuk memperoleh gambaran pelaksanaan penerapan pembelajaran daring.

Proses pengumpulan data dalam penelitian ini yaitu dengan mengumpulkan data-data yang telah diambil menggunakan teknik observasi, wawancara angket/kuesioner, pre-test \& post-test, dan dokumentasi.

Teknik analisis data yang digunakan dalam penelitian ini adalah deskriptif, yaitu mendeskripsikan data yang diperoleh

Bentuk tes yang digunakkan dalam penelitian ini adalah tes tertulis dalam bentuk tertulis dalam bentuk objektif. Data hasil belajar yang diperoleh dari nilai pretest dan posttest yang diberikan pada awal dan akhir pembelajaran. Analisis keteracapaian hasil belajar peseserta didik secara umum dapat digambarkan dengan deskripsi terhadap nilai rata-rata hasil belajar peserta didik di dalam kelas. Rumus yang dugunakkan untuk melihat nilai rata-rata kelas yaitu:

Keterangan:

$$
\mathrm{X}^{-}=\frac{\mathrm{X} 1+\mathrm{X} 2+\ldots+\mathrm{Xn}}{\mathrm{N}}
$$

$\mathrm{X}^{-}=$Nilai rata-rata kelas

$\mathrm{X} 1+\mathrm{X} 2+\ldots+\mathrm{Xn}=$ Jumlah nilai siswa keseluruhan

$\mathrm{N}=$ Jumlah seluruh siswa (Subana, 2005)

Data nilai tas hasil belajar dianalisis dengan rumus presentasi ketuntasan belajar individu yaitu:

$$
\text { Ketuntasan individual }=\frac{\text { Jumlah skor yang diperoleh }}{\text { Skor maksimum }} \times 100 \%
$$

(Subana, 2005)

Untuk mengukur hasil belajar kognitif digunakan data hasil pre-test dan post-test. Sehingga hasil belajar merupakan selisih hasil dari hasil pre-test dan post-post. Dengan menggunakan rumus $\mathrm{N}$-gain (normalitas gain). Adapun rumusnya adalah sebagai berikut:

$$
N-\operatorname{gain}(g)=\frac{\text { skor posttest }(\%)-\text { skor pretest }(\%)}{\text { Skor ideal }- \text { skor pretest }(\%)}
$$

\section{Keterangan:}

$\mathrm{N}$-gain Tinggi $=$ Nilai $(0,70<\mathrm{g}<1,00)$

$\mathrm{N}$-gain Sedang $=$ Nilai $(0,3<\mathrm{g}<0,7)$

$\mathrm{N}$-gain rendah $=$ Nilai $(\mathrm{g}<0,3) \_(\text {Herlanti, 2015) }$

\section{Hasil dan Pembahasan}

\section{Efektivitas Pembelajaran Daring Peserta Didik}

Menurut Afifatu (dalam Fathurrachman dkk, 2019) efektivitas pembelajaran adalah ukuran keberhasilan dari suatu proses interaksi antar siswa maupun antara siswa dengan guru dalam situasi edukatif untuk mencapai tujuan pembelajaran. Sementara menurut Bates (2020) pembelajaran daring merupakan bentuk pendidikan jarak jauh yang penyampaian materinya dilakukan melalui internet (dalam jaringan). Berdasarkan dari 
pernyataan diatas, dapat disimpulkan bahwa untuk mencapai pembelajaran daring yang efektif diperlukan beberapa perencanaan yang harus dilakukan oleh guru. Sani (2015) juga menyatakan bahwa pembelajaran yang efektif tidak terlepas dari peran guru yang efektif, kondisi pembelajaran yang efektif, keterlibatan peserta didik, dan lingkungan belajar yang mendukung.

Pada penelitian yang dilaksanakan di SMA Terpadu Wira Bhakti Gorontalo ini ditemukan bahwa telah melakukan pembelajaran daring sejak bulan Maret tahun 2020 dan telah melakukkan beberapa perencanaan proses pembelajaran daring yang dapat digunakkan dengan mudah oleh guru dan peserta diidk dengan melalui beberpa fitur maupun aplikasi. Hal ini diperkuat dengan pernyataan - peryataan pada angket yang diberikan peneliti kepada peserta didik pada saat penelitian.

\section{a. Hasil Wawancara}

Wawancara digunakan sebagai data pendukung teknik angket dalam pengumpulan data apabila teknik angket kurang mendalam dari informan peserta didik. Berikut adalah cuplikan wawancara peneliti dengan Guru mata Pelajaran Biologi :

Peneliti : Bagaimana proses pembelajaran selama pandemi covid-19 saat ini?

Guru : "Untuk saat ini khususnya pada mata pelajaran biologi ada beberapa kendala yah, termasuk kendala dalam persoalan jaringan. Untuk perserta didik yang ada di SMA Terpadu Wira Bahkti Gorontalo juga itu rata - rata di luar daerah Gorontalo, misalnya di daerah Bolaang Mongodow Selatan, Bolang Mongodow Timur dan ada juga yang di Sulawesi Tengah, bahkan ada juga yang di Papua. Contohnya yang ada di Bolaang Mongondow Selatan, ada desa atau tempat - tempat tertentu yang tidak ada jaringannya, sehingga mereka harus pergi ke kampung sebelah yang jaraknya lumayan jauh untuk mengikuti pembelajaran daring karna jaringan disana ada dan tidak loading. Kemudian kendala yang berikutnya, peserta didik yang biasanya kita aktif tapi meraka tidur bahkan biasanya mereka hanya sengaja ikut dalam pembelajaran tapi mereka tidak ada dipembelajaran tersebut".

Peneliti : Bagaimana tanggapan Bapak mengenai pembelajaran saat ini?

Guru : : Untuk pembelajaran saat ini daring. Pembelajaran daring tidak efektif. Kenapa tidak efektif? Yang pertama, kita mau menjelaskan yang ada kaitannya misalnya pengalaman mereka langsung, dan bertatap muka langsung dengan guru. Itu mereka tidak rasakan. Begitupun dengan teoriteori yang disampaikan itu mereka tidak pahami. Ketika ada ulangan itu mereka hanya terpaku di buku jadi pertanyaan tidak berkembang dan jawabannyapun tidak berkembang"

Peneliti : Media apa yang digunakan pada saat proses pembelajaran daring saat ini?

Guru :'Media/aplikasinya yang kita gunakkan yaitu Teams, itu dari Kementrian Pendidik dan Budaya langsung. Nah di Teams itu sudah lengkap, baik dari mengantur jadwal mata pelajarannya, kita chatingan dengan peserta didik, kemudian ada juga aplikasi di dalamnya bisa buat penugasan, semuanya lengkap".

Peneliti : Apakah proses pembelajaran yang dijalani saat ini efektif dalam mencapai harapan dari peserta didik?

Guru :'Masing - masing punya fenomena pengalaman yang berbeda, khususnya Bapak sendiri di mata Pelajaran Biologi di kelas X ini, saat- saat tidak efektif. Seperti yang yang Bapak sudah katakana tadi diawal. Kenapa?...karna ada bererapa teori yang mereka harus butuh pengalaman langsung di lapangan, kemudian ada penguatan - penguatan. Tapi karna 
ada kendala jaringan atau bahkan memori penyimpanan Hp peserta didik telah mencapai batas maksimum penggunaan, dan beberapa kendala lainnya lagi”.

Peneliti : Apakah ada peserta didik yang sulit memahami materi pelajaran biologi khsususnya materi Ruang Lingkup Biologi dengan pembelajaran daring saat ini?

Guru $\quad$ :"Iya ada. Ada beberapa peserta didik. Di materi Ruang Lingkup itu sendiri juga kan kita lihat peserta didik itu harus ada pengalaman langsung. Contohnya seperti di laboratorium, di laboratorium itu kita langsung memberikan pengetahuan ke meraka (ini alat untuk praktikum apa, ini bahan untuk apa, bagaimana cara - caranya ini, kemudian tata tertib di laboratorium itu seperti apa). Nah itu mereka yang tidak temukan walaupun kita sudah mencari beberapa video tentang ruang lingkup tapi mereka ini seperti tidak ada pengalaman langsung yang mereka rasakan, pada saat tes atau ulangan ituu menjadi kendala"

Peneliti : Bidang apa yang diperbaiki agar pembelajaran daring saat ini berjalan lebih baik lagi?

Guru :"Banyak aspek yang perlu diperbaiki. Contoh misalnya, harus ada kerja sama dengan orang Tua. Ada beberapa solusi misalnya, peserta didik Hpnya android bagus tapi jaringan yang ada di daerahnya kadang tidak mendukung sehingga dari oramg Tua memberikan informasi ke kita Guru bahwa anak ini tidak ikut karna persoalan seperti ini sehingga absensinsinya diguru itu jelas. Nah di kami guru juga kita akan bangun komunikasi sesuai dengan protokol kesehatan mungkin kalau cuman persoalan peserta didik dengan jumlah 1 atau 2 oarang bermasalah kita bisa datang langsung ke rumahnya atau melakukkan pembelajaran luring dan seraya juga mencari solusi. Bapak rasa hanya komunikasi ini yang bisa dibangun karna kita menggunakan sistem jaringan sekarang”.

Berdasarkan hasil wawancara dengan guru mata pelajaran Biologi kelas X di SMA Terpadu Wira Bhakti Gorontalo dapat dilihat bahwa Efektivitas pembelajaran daring peserta didik pada mata pelajaran biologi khususnya materi ruang lingkup biologi untuk saat ini tidak Efektif dikarenakan ada beberapa kendala termasuk kendala dalam persoalan sinyal/jaringan yang kurang memadai atau bahkan jaringannya tidak ada sama sekali, kemudian memori penyimpanan handphone peserta didik yang telah mencapai batas maksimum penggunaan, tidak adanya pengalaman langsung di lapangan, kemudian kendala yang berikutnya, peserta didik yang biasanya aktif menjadi tidak aktif dalam pembelajaran daring tersebut karena ada beberapa meraka tidur bahkan biasanya mereka hanya sengaja ikut dalam pembelajaran.

Peneliti : Apakah Bapak mengalami kendala mengenai kecepatan dalam menyampaikan informasi kepada siswa?

Guru : "Banyak sekali kendala masalah yang dihadapi terutama ditempat kita ini, karena kondisi signal termasuk lampu yang kadang mati, kalau lampu mati kalau jaringan seperti XL yang banyak dipakai siswa yang lebih murah ya biasanya ikut mati mungkin kesusahan untuk menggunakan seperi Google Form kemudian model Zoom ya termasuk juga masalahnya kuota bagi anak karena waktu pembelajaran daring awal tidak ada bantuan dari sekolah $y a "$

Peneliti : Bagaimana menurut Bapak respon yang diberikan oleh siswa mengenai penyampaian materi atau tugas yang diberikan? 
Guru

Peneliti

Guru

Peneliti

Guru

: "Selama ini memang banyak keluhan sekali dari siswa terutama karena dia memang terbiasa dengan tatap muka belajar dikelas tiba-tiba mereka harus belajar menggunakan daring dengan berbagai media-media yang belum mereka kenal yang mereka kenal mungkin hanya sebatas WA itu mungkin bagi guru memberikan tugas segala macam memberikan tugas masih bisa tetapi kalau menggunakan yang lain seperti Google form, Google Classroom mungkin mereka juga harus belajar lagi seperti siswa yang lainnya"

: Bagaimana tanggapan Bapak mengenai pemanfaatan daring saat ini?

: "Ya cukup memuaskan untuk pemanfaatan daring untuk pembelajaranpembelajaran saat ini seperti penggunaan-penggunaan internet kemudian manfaatnya bagi siswa yang tidak terbiasa mungkin dengan menggunakan model-model pembelajaran atau tidak, mungkin bahkan tidak pernah sama sekali buka WA itu bagi dia penting ya apalagi kalau dikurikulum 2013 kita mengenal yang namanya literasi. Literasi diberikan kepada siswa sebelum pembelajaran dimulai jadi siswa diberi kesempatan untuk membaca buku sebelum kita melaksanakan pembelajaran kalau ditatap muka dulu memang waktunya yang terbatas tapi kalau dipembelajaran daring banyak kesempatan siswa untuk membuka, mengakses bacaan-bacaan yang lain selain yang kita pelajari disekolah"

: Apakah Bapak merasa nyaman dengan penggunaan pembelajaran daring saat ini?

: "Kalau ditanya nyaman ya terkadang ada nyamannya, tidak harus pergi kesekolah tatap muka tetapi kalau merasa tidak nyamannya terkadang juga ada dan juga tidak merasa nyamannya seperti kalau kita kasih tugas kepada siswa yang seharusnya kalau pada saat ulangan itu terkadang 95\% yang hadir mengikuti ulangan yang sisanya mungkin melaksanakan remedial tetapi pada pembelajaran daring mungkin hanya ada pada saat ulangan pertama hanya ada 10 siswa yang mengerjakan nanti itu pun dilakukan secara bertahap supaya siswa yang lain juga mendapatkan nilai yang sama, ya tidak sesempurna pada saat pembelajaran tatap muka"

Dari peryataan guru diatas, maka dapat dikatakan ada banyak kendala yang masih dihadapi guru dan peserta didik namun terlihat cukup jelas bahwa guru matapelajaran biologi terus berusaha memberikan kemudahan dan kesempatan kepada semua peserta didik untuk dapat ikut dalam proses pembelajaran baik itu dari pengumpulan tugas hingga ujian dengan tujuan agar peserta didik mendapatkan nilai perolehan hasil belajar, sementara jika dilihat dari sisi para siswa maka tanggapan mereka cukup berbeda, dari pernyataan beberapa siswi dapat disimpulkan bahwa masih ada peserta didik yang kurang memahami tentang pembelajaran dalam jaringan. Hal ini berarti akan menjadi pengalaman pertama bagi peserta didik dalam proses pembelajaran yang dianggap baru dan masih asing. Tidak hanya itu, dari beberapa pernyataan tersebut juga dapat disimpulkan bahwa peserta didik juga sangat memerlukan biaya untuk proses pembelajaran.

\section{b. Aplikasi WhatsApp}

Menurut pendapat Enterprise (2012) whatsapp merupakan aplikasi chatting dimana anda dapat mengirim pesan teks, gambar, suara, lokasi, dan bahkan video kepada temanteman anda menggunakan ponsel apapun. Dari pernyataan ini, maka tidak heran jika banyak guru yang lebih memilih untuk memanfaatkan aplikasi ini untuk mempermudah proses pembelajaran daring saat ini. Seperti pernyataan sebelumnya dari guru matapelajaran ekonomi, yang menyebutkan bahwa salah satu media pembelajaran daring 
yang digunakan adalah aplikasi whatsapp. Hal ini diperkuat dengan pernyataan guru sebagai berikut:

"kalau untuk mengakses paling mudah digunakan ya Whatsapp karena apalagi kita dibuat group siswa karena lebih mudah"

Hal ini juga dinyatakan oleh salah seorang peserta didik yang menjadi narasumber dalam penelitian ini yang menyebutkan bahwa:

"Jadi guru langsung kasih tugas digroup kelas"

Adapun mengenai group whatsapp yang dikemukakan peneliti yang dapat dilihat pada Gambar 1.
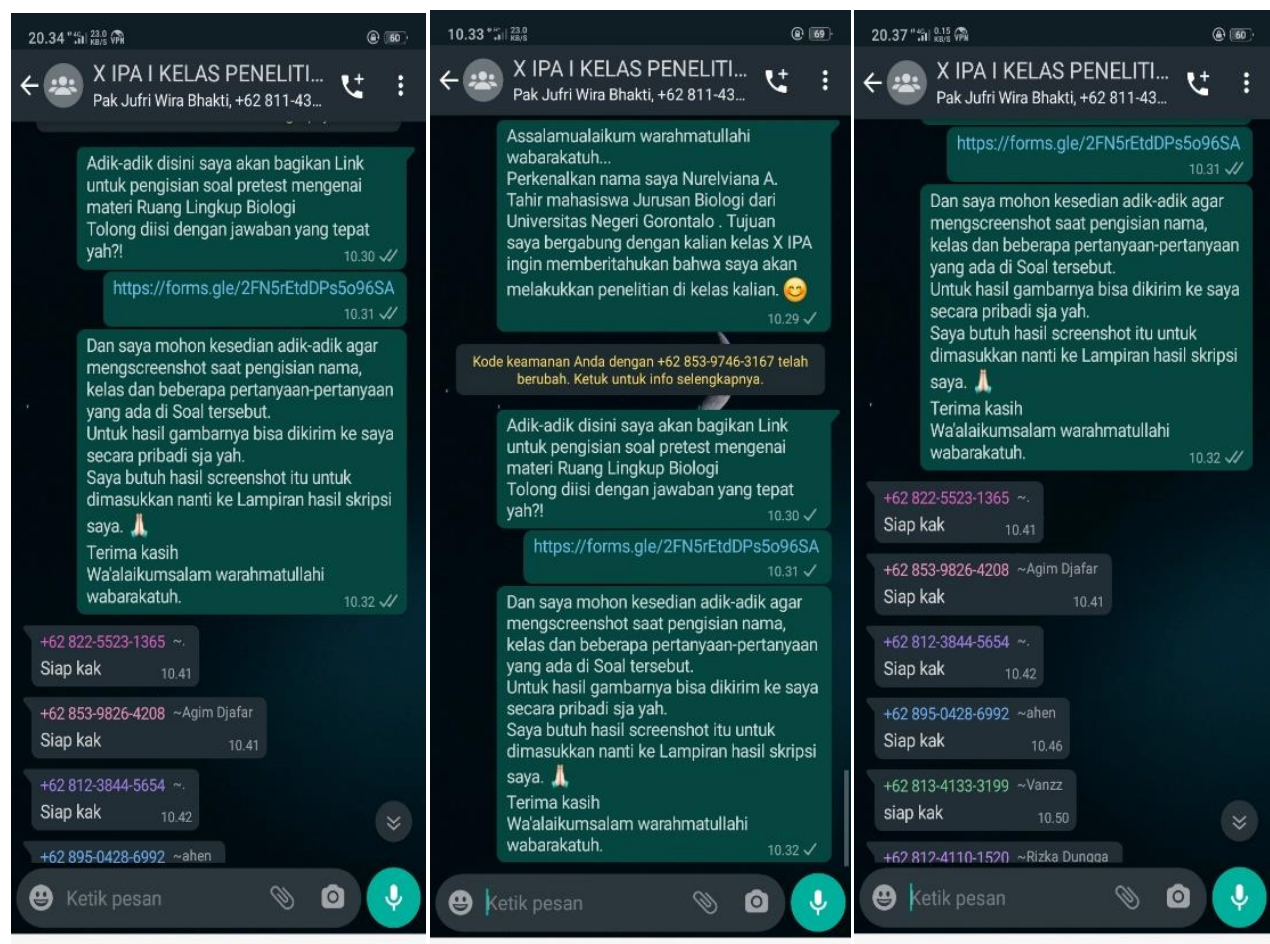

Gambar 1. Group Chat Whatsapp kelas XI IPA

\section{Sumber: Screenshoot group i whatsapp}

Seperti pernyataan guru sebelumnya tentang group kelas, dari gambar ini terlihat beberapa percakapan peserta didik yang tergabung dalam sebuah group kelas yang dimana peneliti memberikan intruksi agar dapat mengakses link pretest terkait materi ruang lingkup biologi yang telah disediakan oleh peneliti sebelumnya.

Pada aplikasi ini, tersedia pula untuk peserta didik dapat melakukan komunikasi secara personal kepada guru dan begitu pun sebaliknya yang didukung dengan berbagai fitur yang dapat bermanfaat bagi penggunanya, mulai dari dapat mengirim dan menerima dalam bentuk gambar, suara, file, bahkan video. Jika berbicara mengenai komunikasi personal maka siswa dan guru matapelajaran Biologi di SMA Terpadu Wira Bhakti Gorontalo pun juga menggunakan fitur tersebut dalam proses pembelajaran. Hal ini kemukakan oleh beberapa narasumber ketika peneliti bertanya mengenai penggunaan chat personal antara guru dan peserta didik.

Peneliti : Apakah Bapak dapat melakukan chat secara personal kepada siswa?

Guru : "Tentu saja bisa, selama ini juga misalnya kita memberi tugas kepada siswa ya siswa langsung chat keguru yang bersangkutan, apakah tugasnya 
sudah dinilai atau bahkan mungkin ada yang bertanya langsung tugas yang selanjutnya atau yang tidak dimengerti bisa langsung ke guru yang bersangkutan"

Peneliti : Apakah siswa dapat melakukan chat secara personal kepada guru?

Siswa : "Bisa kak, kalau ngumpulkan tugas lewat WA pribadi guru bae, dak bisa nemuin gurunya soalnya"

Dari hasil wawancara mengenai penggunaan chat personal dapat diketahui bahwa siswa dan guru dapat berkomunikasi secara langsung melalui chat pribadi yang digunakan untuk mengumpulkan tugas mau pun dapat bertanya langsung jika ada materi yang kurang dipahami oleh siswa, informasi ini diperoleh peneliti pada saat melakukan wawancara dengan salah satu guru matapelajaran.

\section{c. Fitur Microsoft teams}

Microsoft teams adalah produk layanan berlangganan yang ditawarkan oleh Microsoft sebagai bagian dari lini produk Microsoft Office. Secara umum, fasilitas Microsoft 365 terdiri dari perangkat lunak Microsoft Office serta perangkat lunak berbasis komputasi awan sebagai produk layanan untuk lingkungan bisnis, seperti Hosting Exchange Server, Skype for Business Server, dan SharePoint ditambah opsi tambahan layanan Windows 10 Enterprise. Semua paket Microsoft 365 diperbarui otomatis tanpa biaya tambahan.

Microsoft Teams adalah hub digital aplikasi cloud yang menyatukan percakapan, rapat, file, dan aplikasi dalam satu Sistem Manajemen Pembelajaran (LMS) tunggal (Microsoft, 2018). Aplikasi adalah kependekan dari aplikasi, yang identik dengan program perangkat lunak. Sementara aplikasi dapat merujuk ke program untuk platform perangkat keras apa pun, itu paling sering digunakan untuk menggambarkan program untuk perangkat seluler, seperti ponsel cerdas dan tablet (Techterms.com, 2019).

Microsoft juga menggunakan bot istilah dalam literatur tentang Tim; Christensson (2019) mendefinisikan bot - kependekan dari robot - sebagai program otomatis yang berjalan melalui Internet. Beberapa bot berjalan secara otomatis, sementara yang lain hanya menjalankan perintah ketika mereka menerima input tertentu. Seorang tutor dapat mengetik "jadwal rapat" ke dalam obrolan, dan bot akan mengumpulkan informasi dan kemudian menjadwalkan rapat dan mengundang anggota staf siswa lainnya (Microsoft, 2018).

Pada penelitian ini, menurut guru matapelajaran biologi SMA Terpadu Wira Bhakti Gorontalo sejak pembelajaran daring, guru memanfaatkan Microsoft teams dalam proses evalusi pembelajaran siswa. Pernyataan ini disebutkan oleh guru pada sesi wawancara dengan peneliti.

"Kalau untuk pembelajaran daring kemarin saya kebetulan hanya menggunakan WA untuk matapelajaran Biologi kemudian sambil belajar saya juga untuk ulangan harian kemudian ulangan semester sudah bisa menggunakan Microsoft Teams yang merupakan platfom yang sudah dianjurkan oleh kemendikbud"

Dari pernyataan ini dapat diketahui bahwa pada pembelajaran biologi guru menggunakan platfom Microsoft Teams untuk proses pembelajaran siswa. Sementara untuk mengakses Microsoft Teams yang telah disediakan oleh guru, siswa dapat mengakses melalui link yang diberikan oleh guru melalui whatsapp. 

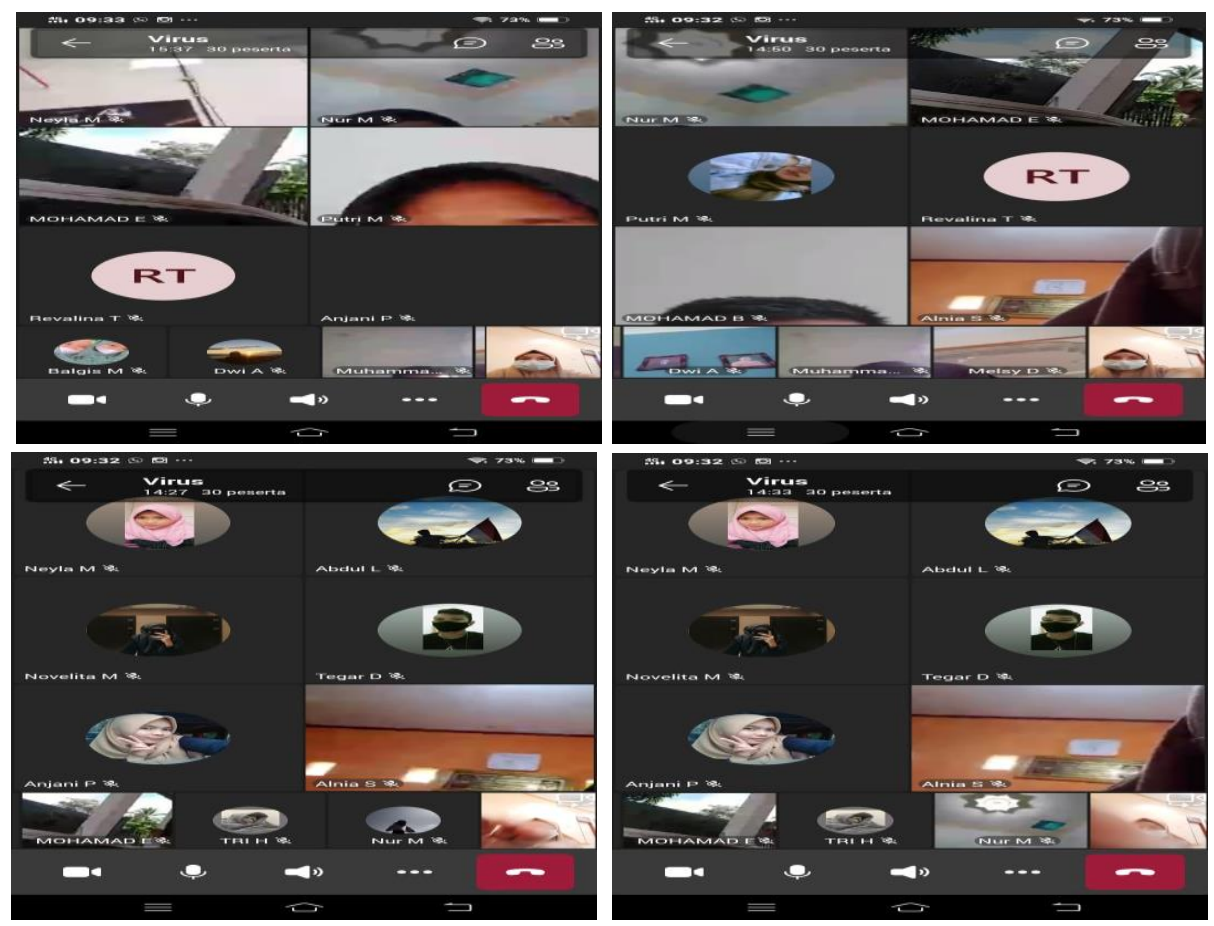

\section{Gambar 2. Aktifitas Belajar melaluai aplikasi Microsoft Teams}

\section{Sumber: Screenshoot dari salah satu handphone siswa}

Dari hasil wawancara mengenai kendala penggunaan Microsoft Teams dapat dilihat bahwa sebenarnya Microsoft Teams sudah sangat membantu pembelajaran, namun dari sisi guru kendala yang dihadapi pada saat pembuatan soal yang dimana dikarenakan sebelumnya guru belum mengetahui banyak mengenai Microsoft Teams. Sementara dari sisi siswa kendala yang dihadapi lebih dominan error pada saat mengakses Microsoft Teams baik itu karena sinyal yang kurang memadai atau bahkan karena memori penyimpanan handphone siswa yang telah mencapai batas maksimum penggunaan.

\section{d. Kemudahan dan Kendala Dalam Pembelajaran Daring}

Dari hasil observasi dan didukung oleh hasil penelitian berupa wawancara yang telah dilakukan maka dapat ditarik kesimpulan bahwa ada beberapa kemudahan atau kelebihan yang dapat diperoleh dari pembelajaran daring tersebut. Namun ada beberapa hal juga yang menjadi kendala utama dalam proses pembelajaran daring pada mata pelajaran biologi. Adapun kemudahan atau kelebihan dan kendala-kendala tersebut sebagai berikut:

1. Kemudahan atau kelebihan dalam proses pembelajaran daring

1) Proses pembelajaran dapat dilakukan dimana saja dan kapan saja. Ini berarti siswa memiliki waktu yang cukup untuk belajar.

2) Guru dan siswa dapat menambah pengetahuannya mengenai pemanfaatan teknologi informasi yang digunakan dalam bidang pendidikan.

3) Guru dan siswa memiliki sumber belajar yang sangat luas.

4) Menambah variasi dalam belajar.

5) Menumbuhkan rasa mandiri dan kesadaran siswa untuk belajar.

6) Siswa dapat memanfaatkan berbagai fitur belajar online, mulai dari yang gratis hingga yang berbayar.

7) Siswa dapat dengan mudah melakukan diskusi baik itu dengan guru maupun dengan siswa lainnya mengenai pembelajaran.

2. Kendala-kendala yang dihadapi dalam proses pembelajaran daring 
1) Penggunaan media daring, ada beberapa siswa yang sebelumnya tidak memahami penggunaan Microsoft Teams.

2) Jaringan internet,

3) Listrik

4) Kuota internet, merupakan kendala yang cukup berat bagi siswa.

5) Jadwal pelajaran, terkadang ada beberapa guru yang tidak mengikuti jadwal pelajaran yang telah ditetapkan sehingga pembelajaran akan bertabrakan yang membuat tugas siswa semakin menumpuk.

6) Motivasi siswa, tidak semua siswa dapat termotivasi dengan adanya pembelajaran daring ini ditambah lagi kendala jaringan, paket data,tugas

7) Error, salah satu penyebabnya ialah penyimpanan handphone siswa yang tidak cukup sehingga pada saat mengakses Microsoft Teams bahkan whatsapp akan mengalami error.

8) Berkurangnya interaksi antara guru dan siswa maupun siswa dengan siswa. Walaupun siswa dan guru dapat berkomunikasi secara online, namun akan terasa lebih leluasa jika berkomunikasi secara tatap muka langsung.

9) Kurangnya pengawasan siswa dalam belajar, tidak semua orang tua dirumah dapat mengawasi anaknya dalam proses pembelajaran sehingga terkadang siswa kehilangan fokus dalam belajar.

\section{e. Hasil Belajar pre-test \& post-test}

Menurut Susanto (2016) hasil belajar dapat dimaknai sebagai suatu perubahanperubahan yang dialami siswa itu sendiri, baik menyangkut aspek kognitif, prikomotik, dan afektif sebagai hasil kegiatan belajar yang telah dilakukan. Pada penelitian ini, standar KKM yang ditetapkan untuk matapelajaran biologi yaitu sebesar 70. Pada saat observasi dilakukan terlihat nilai rata-rata peserta didik dari kelas X IPA mampu mencapai standar KKM yang ditetapkan pada pembelajaran sebelum daring dilakukan (tatap muka).

Pembelajaran daring merupakan pendidikan formal yang diselenggarakan oleh sekolah yang siswa dan guru berada dilokasi yang berbeda sehingga memerlukan sistem komunikasi interaktif untuk menghubungkan keduanya dan berbagai sumber daya yang dibutuhkan didalamnya. Pembelajaran ini dapat diakukan dimana saja dan kapan saja tegantung pada ketersediaan alat pendukung yang digunakan (Meidawati, dkk dalam Pohan, 2020).

Pembelajaran daring merupakan pembelajaran yang telah dilaksanakan di SMA Terpadu Wira Bhakti Gorontalo. Pada proses pembelajaran matapelajaran biologi ini, diketahui guru dan siswa sepakat untuk menggunakan aplikasi whatsaap dan fitur Microsoft Teams sebagai media pembelajaran daring untuk membantu proses pembelajaran biologi. Adapun beberapa manfaat dari aplikasi whatsaap yaitu dapat bertukar informasi dalam bentuk pesan teks, gambar, suara, lokasi, video, hingga file dalam format $p d f$, doc, dan lainnya. Sementara fitur Microsoft Teams dapat digunakan untuk membantu proses evaluasi dan penilaian hingga absensi siswa.

Berdasarkan hasil wawancara yang telah dilakukan peneliti, diketahui bahwa dikarenakan adanya pandemi COVID-19 dan intruksi dari dinas pendidikan maka pembelajaran tatap muka yang biasanya dilakukan pada proses pembelajaran untuk sementara waktu diganti menjadi pembelajaran daring. Dengan diberlakukannya pembelajaran daring ini tentu guru mengkhawatirkan masalah-masalah yang mungkin akan terjadi pada proses pembelajaran yang akan dilakukan mengingat sebelumnya para siswa telah terbiasa dengan pembelajaran tatap muka dan guru juga masih belum terbiasa dengan pembelajaran menggunakan Microsoft Teams. Hal ini pun harus ditanggapi serius dengan guru dan pihak sekolah dengan memberikan kebebasan para guru untuk menggunakan 
media daring apa saja yang telah disepakati oleh guru dan siswa agar proses pembelajaran dapat dilakukan semudah dan senyaman mungkin untuk siswa dan guru.

Dari wawancara mengenai media daring, guru dan siswa sepakat untuk menggunakan media aplikasi whatsapp dan Microsoft Teams yang dimana aplikasi whatsapp digunakan untuk berkomunikasi dengan siswa baik itu melalui group kelas maupun secara pribadi. Penggunaan aplikasi ini dalam pembelajaran yaitu, siswa akan diberikan tugas melalui perintah langsung dari guru yang biasanya melalui group whatsapp yang telah ditentukan sebelumnya, baik itu berupa tulisan, voice note, video pembelajaran maupun dalam bentuk gambar dan siswa akan menjawab pertanyaan guru dengan cara mengirimkan jawaban sesuai perintah yang telah di berikan oleh guru. Seperti pengumpulan tugas berupa gambar, file pdf, maupun rekaman video. Aplikasi ini pun merupakan aplikasi yang paling umum digunakan oleh masyarakat dan mudah untuk diakses sehingga siswa tentunya sudah tidak asing dengan aplikasi tersebut.

Sementara Microsoft Teams digunakan untuk absensi, ulangan dan ujian semester. Microsoft Teams ini merupakan salah satu fitur yang disediakan oleh goole dan fitur ini menjadi salah satu media daring yang digunakan pada mata pelajaran biologi di SMA Terpadu Wira Bhakti Gorontalo. Namun fitur ini belum terbiasa digunakan oleh siswa dan guru sebelumnya sehingga guru sedikit mengalami kendala untuk awal-awal penggunaan dan siswa terkendala dengan kuota yang terbatas, signal yang kadang terganggu belum lagi ada lokasi beberapa siswa yang masih kurang terjangkau jaringan hingga handphone yang terkadang error karena kapasitas penyimpanan yang telah memenuhi maksimum penggunaan, menurut guru biologi, ada banyak sekali keluhan siswa dalam pembelajaran daring tersebut mengingat siswa hanya terbiasa dengan penggunaan aplikasi whatsapp sehingga siswa masih harus belajar lagi mengenai penggunaan Microsoft Teams. Sementara menurut siswa, mereka kaget karena harus belajar secara daring yang sebelumnya belum pernah mereka lakukan. Ditambah lagi mereka harus mengeluarkan biaya untuk memenuhi penggunaan paket data selama daring.

\section{Kesimpulan dan Saran}

Berdasarkan hasil penelitian dan pembahasan dari pengumpulan data yang menjadi fokus dalam penelitian ini yaitu mengenai keefektifan pembelajaran daring (studi kasus hasil belajar mata pelajaran ekonomi EFEKTIVITAS PEMBELAJARAN DARING PESERTA DIDIK (Suatu Penelitian Pada Mata Pelajaran Biologi SMA Terpadu Wira Bhakti Gorontalo) yang telah diuraikan pada bab sebelumnya maka dapat disimpulkan bahwa jika dilihat dari hasil belajar nilai rata-rata mata pelajaran biologi siswa kelas X IPA pada pembelajaran daring semester ganjil 2020/2021 maka dapat dikatakan pembelajaran daring tersebut telah efektif karena dari data yang diperoleh jika dibandingkan dengan hasil belajar siswa kelas X IPA pada semester ganjil maka perolehan hasil belajar siswa pada semester genap ini mengalami peningkatan. Sementara mengenai media daring yang digunakan yaitu aplikasi whatsapp dan microsof teams sudah sangat membantu mempermudah guru dan siswa dalam proses pembelajaran.

Berdasarkan hasil temuan dalam penelitian yang berjudul keefektifan pembelajaran daring (Suatu Penelitian Pada Mata Pelajaran Biologi SMA Terpadu Wira Bhakti Gorontalo), maka peneliti mengajukan saran Berdasarkan hasil temuan dalam penelitian yang berjudul keefektifan pembelajaran daring (Suatu Penelitian Pada Mata Pelajaran Biologi SMA Terpadu Wira Bhakti Gorontalo), maka peneliti mengajukan saran perlunya guru untuk terus meningkatkan kompetensi TIK sehingga guru dapat memanfaatkan aplikasi-aplikasi dan fitur-fitur belajar google dalam proses pembelajaran dan perlunya jadwal belajar yang akurat dan harus di ketahui oleh semua siswa sehingga siswa dapat melakukan persiapan sebelumnya dan perlunya dibangun motivasi siswa untuk belajar daring dikarenakan guru 
tidak dapat membimbing siswa secara langsung sehingga siswa harus belajar secara mandiri.

\section{Daftar Pustaka}

Gikas, J., \& Grant, M. M. (2013). Mobile computing devices in higher education: Student perspectives on learning with cellphones, smartphones \& social media. Internet and Higher Education. https://doi.org/10.1016/j.iheduc.2013.06.002

Khusniyah, N. L. \& Hakim, L. (2019). Efektivitas Pembelajaran Berbasis Daring: Sebagai Bukti Pada Penbelajaran Bahasa Inggris. Jurnal Tatsqif, 17(1), 19-33. DOI: https://doi.org/10.20414/jtq.v17i1.667.

Moore, J. L., Dickson-Deane, C., \& Galyen, K. (2011). E-Learning, online learning, and distance learning environments: Are they the same? Internet and Higher Education. https://doi.org/10.1016/j.iheduc.2010.10.001

Subana, M dan Sudratjat. (2005). Dasar-dasar Penelitian Ilmiah. Bandung: Pustaka setia

Sani, Ridwan Abdullah. 2015. Inovasi Pembelajaran. Jakarta: PT Bumi Aksara

Sugiyono. (2017). Metode Penelitian Kuantitatif Kualitatif dan $R \&$ D. Bandung: Alfabeta.

Sutikno, M. S. (2005). Pembelajaran Efektif. Mataram: NTP Press

Sutopo. (2006). Subana, M dan Sudratjat. (2005). Dasar-dasar Penelitian Ilmiah. Bandung: Pustaka setia Metodologi Penelitian Kualitatif. Surakarta: UNS.

Syarifudin, Albitar S. (2020). Implementasi Pembelajaran Daring Untuk Meningkatkan Mutu Pendidikan Sebagai Dampak Diterapkannya Social Distancing. Jurnal Pendidikan Bahasa dan Sastra Indonesia. 31-33. https://doi.org/10.21107/metalingua.v5i1.7072

Wicaksana, J. E., Atmadja, P., Lestari, W., Tanti, L. A., \& Odrina, R. (2020). Efektivitas Pembelajaran Menggunakan Moodle Terhadap Motivasi dan Minat Bakat Peserta Didik di Tengah Pandemi. Jurnal Edukasi dan Teknologi Pembelajaran, 1(2), 117-124. DOI: https://doi.org/10.37859/eduteach.v1i2.1937

Zhang, D., Zhao, J. L., Zhou, L., \& Nunamaker, J. F. (2004). Can e-learning

Zhang, D., Zhao, J. L., Zhou, L., \& Nunamaker, J. F. (2004). Can e-learning replace classroom learning? Communications of the ACM. https://doi.org/10.1145/986213.986216 